\title{
S1PR4 Gene
}

National Cancer Institute

\section{Source}

National Cancer Institute. S1PR4 Gene. NCI Thesaurus. Code C104779.

This gene encodes a G protein-coupled receptor that may be involved in cell migration processes in lymphocytes. 